\title{
Study of ABO and Rh(D) Blood Groups in Kshatriya (Rajput) of Jaunpur District, Uttar Pradesh
}

\author{
Pradeep Kumar $^{1}$, Vivek Kumar Singh ${ }^{2}$ and Vandana Rai ${ }^{1}$ \\ ${ }^{1}$ Department of Biotechnology, 2Department of Applied Biochemistry, V B S Purvanchal \\ University, Jaunpur 222 001, Uttar Pradesh, India
}

KEYWORDS Blood groups, Kshatriya (Rajput), Genetic Variation.

ABSTRACT The present communication reports the distribution of $\mathrm{ABO}$ and $\mathrm{Rh}(\mathrm{D})$ blood groups among 200 unrelated individuals from Kshatriya (Rajput) population of Jaunpur district. The overall ABO percentage is B (36\%)> $\mathrm{O}(33.5 \%)>\mathrm{A}(20.0 \%)>\mathrm{AB}(10.5 \%)$. The frequencies of $\mathrm{Rh}$ positive and Rh-negative individuals are $96.5 \%$ and $3.5 \%$ respectively.

\section{INTRODUCTION}

Blood group systems have been successfully used to study the genetic variation within and between the populations and to evaluate the ethnic variation and affiliation between different populations. In the present study an attempt is made to study the distribution of $\mathrm{ABO}$ and $\mathrm{Rh}(\mathrm{D})$ blood group systems among the Kshatriya (Rajput) population of district Jaunpur, Uttar Pradesh.

\section{MATERIALS AND METHODS}

The blood samples were drawn from randomly selected 200 unrelated Kshatriya individuals of both sexes from Jaunpur district of Uttar Pradesh. The samples were analyzed for the $\mathrm{ABO}$ and $\mathrm{Rh}(\mathrm{D})$ blood groups using standard antisera
(Bhasin and Chahal 1996). Gene frequencies were calculated according to the method of Mourant et. al. (1976). The details of each subject such as name, age, sex etc. were collected using a brief questionnaire.

\section{RESULTS AND DISCUSSION}

Distribution of the $\mathrm{ABO}$ and $\mathrm{Rh}(\mathrm{D})$ blood groups among Kshatriya and their allele frequencies is presented in table 1 and 2 respectively. It is observed that in the present population B phenotype recorded highest frequency $(36.0 \%)$ followed by $\mathrm{O}(33.5 \%)$, $\mathrm{A}(20.0 \%)$ and $\mathrm{AB}(10.5 \%)$. The order of $\mathrm{ABO}$ percentage frequencies are $\mathrm{B}>\mathrm{O}>\mathrm{A}>\mathrm{AB}$. The frequency of $A, B$ and $O$ alleles among the Kshatriya population is $0.165,0.267$, and 0.568 , respectively.

Table 1: Distribution of the ABO blood group and their allele frequencies among the Kshatriya (Rajput).

\begin{tabular}{lcccc}
\hline Phenotype & Observed number & $\%$ & Expected number & Allele frequency \\
\hline $\mathrm{O}$ & 67 & 33.5 & 64.5 & $A=0.165$ \\
$\mathrm{~A}$ & 40 & 20.0 & 43.0 & $B=0.267$ \\
$\mathrm{~B}$ & 72 & 36.0 & 74.9 & $0=0.568$ \\
$\mathrm{AB}$ & 21 & 10.5 & 17.6 & 1.000 \\
\hline Total & 200 & 100.0 & 200.0 & 1 \\
\hline
\end{tabular}

Corresponding Author:

Pradeep Kumar, Lecturer,

Department of Biotechnology,

V B S Purvanchal University, Jaunpur 222001 , Uttar Pradesh, India

Telephone: 05452252538(O), 09451713485(M)

E-mail:pradipk14@yahoomail.co.in,

Pradeepk14@rediffmail.com
Table 2: Distribution of the $\operatorname{Rh}(\mathrm{D})$ blood group and their allele frequencies among the Kshatriya (Rajput).

\begin{tabular}{lcrc}
\hline Phenotype & $\begin{array}{c}\text { Observed } \\
\text { number }\end{array}$ & $\%$ & $\begin{array}{c}\text { Allele } \\
\text { frequency }\end{array}$ \\
\hline Rh(D) Positive & 193 & 96.5 & $D=0.813$ \\
Rh(D) Negative & 07 & 3.5 & $d=0.187$ \\
\hline Total & 200 & 100.0 & 1.000 \\
\hline
\end{tabular}


Out of the 200 subjects tested, 193 (96.5\%) were found to be $\mathrm{Rh}$ positive and 7(3.5\%) were Rh negative. The frequency of $D$ and $d$ alleles is 0.813 and 0.187 respectively (Table 2 ).

The distribution of allele frequencies of $\mathrm{ABO}$ and $\mathrm{Rh}(\mathrm{D})$ blood groups of Kshatriya population of Jaunpur district are found to be similar to that observed for Kshatriya population of Himanchal Pradesh (Mukhopadhyay and Kshatriya 2004).

\section{REFERENCES}

Bhasin MK Chahal SMS 1996. A Laboratory Manual for Human Blood Analysis. Delhi: Kamla-Raj Enterprises.

Mourant A E Kopec AC Domaniewska-Sobczak K 1976. The Distribution of the Human Blood Groups and Other Polymorphisms. 2 ${ }^{\text {nd }}$ Edition. London: Oxford University Press.

Mukhopadhyay R Kshatriya GK 2004. Distribution of blood groups among Brahmins and Rajputs of Himanchal Pradesh. Anthropologist, 6(4): 293-294. 